\title{
Toxicological Study Employing Repeated Doses of Garcinielliptone FC, a Polyisoprenylated-Benzophenone Isolated from Seed of Platonia Insignis Mart
}

\author{
Ana P. Silva ${ }^{1}$, José Carlos C. L. S. Filho ${ }^{2}$, Joaquim S. da Costa Júnior ${ }^{3}$, Walter J. Peláez ${ }^{4}$, Martín S. Faillace ${ }^{4}$, \\ Alexandre de B. Falcão Ferraz ${ }^{5}$, Jorge M. David ${ }^{6}$ and Rivelilson M. Freitas ${ }^{1}$ \\ 1. Post-Graduate in Biotechnology, Northeast Biotechnology Network, Federal University of Piauí, Teresina 64048-901, PI, Brazil \\ 2. Department of Computer Science, North Union of Parana, Londrina 86041-140, Brazil \\ 3. Department of Chemistry, Federal Institute of Piaui, Teresina, Piaui 64000-040, Brazil \\ 4. INFIQC-CONICET. Department of Physicalchemistry, Faculty of Chemical Sciences, National University of Córdoba, Córdoba \\ X5000HUA, Argentina \\ 5. Laboratory of Genetic Toxicology, Lutheran University of Brazil, Canoas 92425-900 RS, Brazil \\ 6. Institute of Chemistry, Federal University of Bahia, Salvador, Bahia 40170-290, Brazil
}

\begin{abstract}
The major constituent from the hexane extract of the seeds of $P$. insignis is GFC (garcinielliptone FC). Doses of 25, 50 and $75 \mathrm{mg} / \mathrm{kg}$ of GFC were aseptically suspended in $0.05 \%$ Tween 80 dissolved in $0.9 \%$ saline (vehicle) and orally administered for 30, 90 and 120 consecutive days to adult Swiss mice. In this work, the repeated oral administration, in animals of both sexes, demonstrates that this compound is not able to induce mortality and/or behavioral changes in adult mice. In addition, body weight gain, feed intake and disposal of excreta were not altered by the administration of this compound with repeated doses. Furthermore, no differences in weight and macroscopic structure of the brain, liver, kidney, lung, heart and spleen between groups of male and female adult mice were observed after treatment. During the periods of treatment, GFC produced no significant changes on haematological and biochemical parameters in male and female mice treated with all doses used. The aim of this study was to investigate the toxicological potential of GFC through behavioral, hematological, biochemical and morphological parameters in animals in order to ensure the safe use of Platonia insignis in folk medicine.
\end{abstract}

Key words: Platonia insignis, clusiaceae, polyisoprenylated benzophenones, biochemical analyses, toxicity.

Abbreviations: ALT, alanine aminotransferase; ANOVA, variance; AST, aspartate minotransferase; $\mathrm{CHCl}_{3}-\mathrm{MeOH}$, Chloroform-Methanol; ECEA, Ethics Committee on Experimental Animals; EtOAc, ethyl acetate; FAPEPI, Research Supporting Foundation of the State of Piaui; GFC, Garcinielliptone FC; HB, hemoglobin; i.p., intraperitoneally; MCH, mean corpuscular hemoglobin; MCHC, mean corpuscular hemoglobin concentration; MCV, mean corpuscular volume; MM, male mice; FM, female mice; OECD, Organization of Economic Cooperation and Development's; o.r., orally; RBCs, Hemacias; S.E.M., Standard Error of Mean; TLC, thin layer chromatography; UFPI, Federal University of Piaui; USA, United States of America.

\section{Introduction}

Platonia insignis Mart is a monotype specie that belongs to the Clusioideae family, popularly known as

Corresponding author: Rivelilson Mendes de Freitas, Dr., professor, research director of pharmaceutical technology center and vice-coordinator of the graduation program in pharmaceutical sciences, research field: pharmacy. E-mail: rivmendes@hotmail.com. "bacuri”. It is a fruit and timber specie original from the western Brazilian Amazon, particularly from the State of Pará [1], widely used in folk medicine. The oil from the seeds of $P$. insignis has been used to treat various skin diseases in humans and animals as well as the decoction of seeds has been used for the treatment of diarrhea and inflammatory diseases in 
humans [2, 3].

Previous studies dealing with the chemical composition of the plant family Clusiaceae show that these species are rich in polyisoprenylated xanthones and benzophenones [1, 4-6]. Among these studies, from the hexane extract of the P. insignis seeds, it was isolated a pair of polycyclic polyisoprenylated tautomers, named Garcinielliptone FC (Fig. 1). This compound is unprecedent, in the genus Platonia.

These types of compounds and other benzophenone polyisoprenylated structures, such as 2,4,6-trihydroxy-benzophenone and alkyl aryl ketones have also been isolated from species of the genus Garcinia, Clusia and Rheedia (clusioideae subfamily). They are not only found in the resin, but also in various organs of the plants, which-reinforces the need for developing this study since these compounds may exhibit pharmacological activity of interest in pharmaceutical, cosmetic and/or food industry/field [7-9].

These compounds have shown various pharmacological activities, which can be highlighted the antidepressant [10]; antioxidant [1]; antifungal [11], cytotoxic [12], antiretroviral [11], antibacterial [13] and anticonvulsant [1] effects, suggesting once again that knowledge of its toxicity profile can expand its safer use. Because, as described in the literature, any substance can be considered as a toxic agent [14].
In this context, the aim of this study was to conduct an experimental protocol with repeated doses of GFC in mice to investigate its toxicological potential through behavioral, hematological, biochemical and morphological parameters in animals treated with this compound. The studies were made in order to ensure the safe use of Platonia insignis in folk medicine.

\section{Materials and Methods}

\subsection{Plant Material, Extraction and Isolation}

The seeds were obtained from fruits of specimens collected in the city of Barras, Piaui, Brazil, in March 2009, a voucher specimen (ICN TEPB27164) was deposited in the Herbarium Graziella Barroso, Federal University of Piaui. At first, $848.2 \mathrm{~g}$ of the seeds were dried at $55{ }^{\circ} \mathrm{C}$ and submitted to extraction (soxhlet) with hexane (63\%). Then, the hexane extract was subjected to silica gel eluted with hexane containing increasing amounts of ethyl acetate and washed with methanol to end the process. One of the fractions was purified by TLC (thin layer chromatography) eluted with $\mathrm{CHCl}_{3}-\mathrm{CH}_{3} \mathrm{OH}$ (9:1), obtaining $22 \mathrm{mg}$ of GFC which was identified by means of spectroscopic methods [1].

\subsection{Drugs and Dosages}

The GFC was emulsified in $0.05 \%$ Tween 80 (Sigma Chem. Co., St. Louis, MO, USA) diluted in $0.9 \%$

Fig. 1 Tautomeric forms of
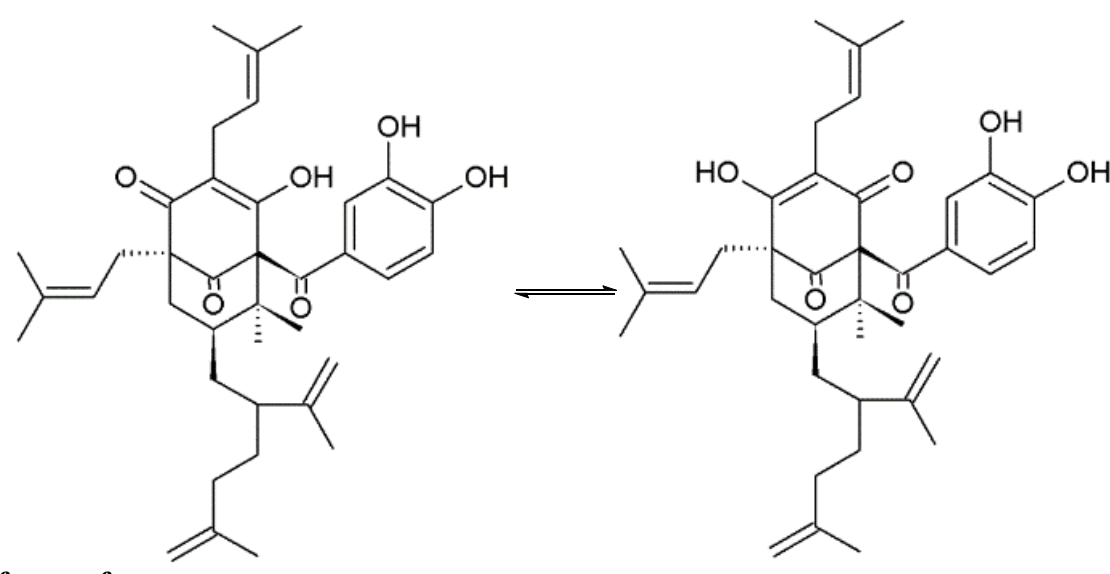

8,8-dimethyl-1-(3,4-dihydroxybenzoyl)-2(4)-hydroxy-3,5-di( $\delta, \delta$-dimethylallyl)-7-(2-isopropenylhex-5-enyl)-7 $\alpha$-H-trans-bicyclo [3.3.1] nona-2-en-4,9-dione (Garcinielliptone FC a) 2-hydroxyl and b) 4 hydroxyl). 
saline (vehicle) and administered orally in selected doses (25, 50 e $75 \mathrm{mg} / \mathrm{kg}$ ), calculated to enable the injection of $0.1 \mathrm{~mL}$ per $10 \mathrm{~g}$ weight of each mouse. The controls received vehicle with the same volume by the same route as the other treated groups.

\subsection{Animals}

All animals were maintained in a controlled temperature $\left(26 \pm 1^{\circ} \mathrm{C}\right)$ and a cycle of $12 \mathrm{~h}$ light/dark. The animals had free access to food and water. All experiments were performed in accordance with the Guide for the Care and Use of Laboratory Animals, Department of Health and Human Services, Washington DC, 1985. The project was approved by the Ethics Committee on Experimental Animals of the Federal University of Piaui (ECEA/UFPI \# 078/2012).

\subsection{Evaluation of the Toxicological Potential}

\subsubsection{Behavioral Screening (Hippocratic Screening)}

The method of Hippocratic Screening for evaluation of toxicity has been a very useful and commonly used method for the preliminary screening of plants and/or to detect chemical compounds with pharmacological and toxicological activities $[15,16]$ as well as the study of physiologic daily habits.

Thirty mice between males and females were divided into three groups of 10 animals weighing 25-30 $\mathrm{g}$ for each dose $(\mathrm{n}=10)$. The animals were treated orally for 30, 90 and 120 consecutive days with repeated doses of 25, 50 e $75 \mathrm{mg} / \mathrm{kg}$ of GFC. During the treatment period, systematic behavioral observations were conducted to evaluate the Hippocratic Screening, which provides a general estimate of the toxicity of the substance on the state of consciousness and general provision, activity and coordination of the motor system, reflexes and activities on the central and autonomic nervous system $[17,18]$.

The parameters: general activity, vocal fremitus, irritability, touch response, contortion, righting reflex, muscle tone, strength to grasp, ataxia, atrial reflex, corneal reflex, tremors, convulsions, straub tail on, hypnosis, anesthesia, lacrimation, ptosis, urination, defecation, piloerection, hypothermia, breathing, cyanosis, hyperemia, death; were evaluated every two days during the period of 30, 90 and 120 days. The administration of the GFC was evaluated daily until the last day of administration. Signs of toxicity, time of onset, intensity, duration and progression were recorded for later analysis.

\subsubsection{Repeated Doses}

Body weight and nutritional status of the animals were quantified and analyzed. The mice were placed individually in cages and acclimated for a period of 15 days. Groups of animals $(n=10)$ were treated daily at the same time, orally (gavage; o.r.) at doses of 25,50 and $75 \mathrm{mg} / \mathrm{kg}$ of GFC or vehicle $(0.1 \mathrm{~mL} / 100 \mathrm{~g}$, o.r.) over a period of 30, 90 and 120 days. The following measures were recorded daily for each animal: the volume of water consumed $(\mathrm{mL})$, the weight of feed consumed (g), the volume of urine excreted $(\mathrm{mL})$ and weight of stools produced (g) besides behavioral changes throughout the study of Cunha et al. [19]. At time intervals of seven days, the animals were weighed for determination of weight gain during the experimental period of 120 days.

2.4.2 Evaluation of Hematological and Biochemical Parameters

Forty mice divided into four groups of 10 animals $(n=10)$ were treated daily orally for up to 120 days, with vehicle (Tween 80 0.05\% dissolved in saline $0.9 \%$, control group) and the doses of 25,50 e 75 $\mathrm{mg} / \mathrm{kg}$ of GFC, respectively $\mathrm{GFC}_{25}, \mathrm{GFC}_{50}$ and $\mathrm{GFC}_{75}$ groups.

After each treatment period, the animals were anesthetized with sodium pentobarbital ( $40 \mathrm{mg} / \mathrm{kg}$, i.p.) and blood collection was performed by puncture of the orbital venous plexus using a needle and syringe microhematocrit tubes. The blood was placed into two kinds of tube: one with anticoagulant hemoglobin $\left(\right.$ Laborlab $^{\circledR}$ ) for determination of hematologic parameters and the other without anticoagulant to 
obtain serum for assessment of biochemical parameters.

The values for erythrocytes, leukocytes, platelets, hemoglobin, hematocrit and RBC indices MCV (mean corpuscular volume), MCH (mean corpuscular hemoglobin) and MCHC (mean corpuscular hemoglobin concentration) were determined immediately after collection using an automated analyzer hematologic cell 120/Hematology Siemens Advia. The differential leukocyte count was performed in extensions stained with May-Grünwald-Giemsa. In each experiment, 100 cells were analyzed and counted.

For biochemical analysis, the material was centrifuged at $3500 \mathrm{rpm}$ for 10 minutes and then determined the glucose, urea, creatinine, AST (aspartate aminotransferase), ALT (alanine aminotransferase), total cholesterol, triglycerides, total and direct bilirubin uric acid. Assays were performed in automatic machine LabMax 240 (Labtest) with commercial systems Labtest $^{\circledR}$.

\subsubsection{Gross Morphological Analysis}

After the treatment period of 120 days with repeated doses of GFC, animals received $40 \mathrm{mg} / \mathrm{kg}$ sodium pentobarbital. According to the protocol of Cornell University/Cornell Center for Animal Resources and Education as described by Flecknell [20] and Kohn et al. [21], mice were euthanized by cervical dislocation to perform the macroscopic evaluation. Therefore, the gross morphological analysis of the naked bodies view was held. In addition, there must had weighted the liver, lung, heart, kidney, brain and spleen to determine the relative weights to check whether there was gross morphological changes in the major organs evaluated.

\subsection{Statistical Analysis}

Results of hematological and biochemical parameters were expressed as mean \pm S.E.M. (Standard Error of Mean). Data were evaluated using variance analysis (ANOVA) followed by t-Student
Newman Keuls test as post hoc test $(P<0.05)$. An estimate of variance was applied for comparison between treated and control groups for each gender group.

\section{Results}

3.1 Study of Toxicity at 30, 90 and 120 Days, Hippocratic Screening

One of the methodologies used to assess the toxic potential of the GFC administered in repeated doses was the analysis of the animals according to the Hippocratic Screening. This technique checks the effects produced by a substance as the state of awareness and provision, coordination, muscle tone, reflexes (ear, corneal), activity of the central nervous system and autonomic nervous system activity of the animal [18].

The Hippocratic Screening of animals treated with repeated doses of GFC in 30, 90120 days are shown in Table 1. Physiological signals were kept steadily in all three doses, with a slight increase after treatments, not significant as clinical signs of toxicity.

During the study, it was observed that among the signs and symptoms that animals presented, there were an attendance of straub, piloerection, lack of response in the grip of the tail and corneal reflection, characteristic manifestations of toxicity but when they occur intensely and associated with other suggestive parameters of toxic processes. In this study, these events were a response to the organic compound studied and are not characteristic of toxicity, since these events were mild and did not cause mortality in animals.

During the Hippocratic Screening, the increased urination and defecation was unobtrusive and may have occurred only by simple manipulation of the animals after administration of the daily doses, since the action of the observer and the change of the eating habits can cause these changes [19]. Nonetheless, this is considered irrelevant for toxicity studies. 
Table 1 Hippocratic Screening of the animals treated with repeated doses of GFC.

\begin{tabular}{|c|c|c|}
\hline $\begin{array}{l}\text { Doses } \\
(\mathrm{mg} / \mathrm{kg})\end{array}$ & $\begin{array}{l}\text { Periods } \\
\text { (Days) }\end{array}$ & Signs and Symptoms \\
\hline \multirow[t]{3}{*}{ Vehicle } & 30 & Absence of signs and symptoms of intoxication. \\
\hline & 90 & Absence of signs and symptoms of intoxication. \\
\hline & 120 & Absence of signs and symptoms of intoxication. \\
\hline \multirow[t]{3}{*}{$\mathrm{GFC}_{25}$} & 30 & Increased urination and defecation. \\
\hline & 90 & $\begin{array}{l}\text { Increased urination and defecation. Presence of straub and piloerection. Lack of response in } \\
\text { the grip of the tail. }\end{array}$ \\
\hline & 120 & $\begin{array}{l}\text { Increased urination and defecation. Presence of straub and piloerection. Lack of response in } \\
\text { the grip of the tail. }\end{array}$ \\
\hline \multirow[t]{3}{*}{$\mathrm{GFC}_{50}$} & 30 & Increased urination and defecation. Presence of piloerection. \\
\hline & 90 & $\begin{array}{l}\text { Increased defecation. Presence of straub and piloerection. Lack of response in the grip of the } \\
\text { tail and corneal reflex. }\end{array}$ \\
\hline & 120 & $\begin{array}{l}\text { Increased defecation. Presence of straub and piloerection. Lack of response in the grip of the } \\
\text { tail and corneal reflex. }\end{array}$ \\
\hline \multirow[t]{3}{*}{$\mathrm{GFC}_{75}$} & 30 & Increased urination and defecation. Presence of straub and piloerection. \\
\hline & 90 & $\begin{array}{l}\text { Increased urination and defecation. Presence of straub and piloerection. Lack of response in } \\
\text { the grip of the tail and corneal reflex. }\end{array}$ \\
\hline & 120 & $\begin{array}{l}\text { Increased urination and defecation. Presence of straub and piloerection. Lack of response in } \\
\text { the grip of the tail and corneal reflex. }\end{array}$ \\
\hline
\end{tabular}

However, even with this understanding, the weights of the animals, the consumption of water and food and excreta presented during the same periods of the Hippocratic Screening assessment were measured to check possible changes in these parameters with an indication of toxicity.

\subsection{Body Weights and Food Consumption of Animals}

During the treatment period, intakes of food (Fig. 2) and water (Fig. 3) of animals were analyzed. The results showed that after the administration, in any of the three doses tested of GFC, food and water consumption were not significantly altered.

Regarding the production of excreta, animals treated with GFC during the three doses did not achieve significant change compared with the control group (Fig. 4), showing weak oscillations according to time and dose.

Body weight of the animals was evaluated, considering ingestion, elimination and weigh. The results showed no significant changes in these parameters even after chronic treatment period or dose increasing. There were slight increases for these two aspects (Fig. 5).

\subsection{Analysis of Hematological and Biochemical Parameters}

Hematological and biochemical parameters are useful for the investigation of systemic toxicity in animals treated for long periods of time with potentially harmful substances [19]. In this study, the results of hematology parameters of the animals treated with GFC are shown in Tables 2 and 3. The data demonstrated that there were no significant changes in the groups treated with GFC, when it was compared to the control group.

During the 30 days treatment with GFC there was a reduction of 5 and $7 \%$ in the MCHC index in male mice treated with doses of 50 and $75 \mathrm{mg} / \mathrm{kg}$ compared with the control group $(P<0.05)$, respectively. As for the females, it was observed a $7 \%$ reduction in this parameter only after the treatment with the dose of 75 $\mathrm{mg} / \mathrm{kg}$ for the same period of observation $(P<0.05)$. During this period of observation, there was a reduction of 14.46 and $15 \%$ in the number of leukocytes in male mice treated with doses of 50 and 
Toxicological Study Employing Repeated Doses of Garcinielliptone FC, a Polyisoprenylated-Benzophenone Isolated from Seed of Platonia Insignis Mart

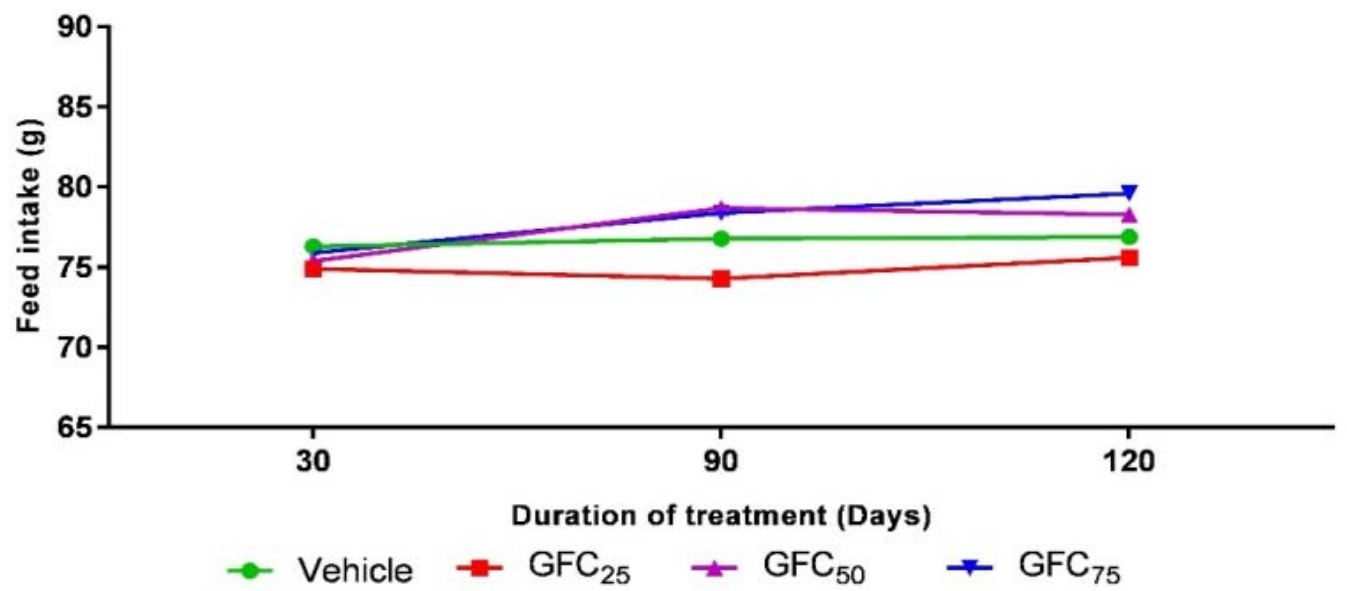

Fig. 2 Effect of oral administration of GFC in repeated doses on the feed intake of the animals.

Statistical analysis was performed using ANOVA followed by t-Student-Newman Keuls-test as a post hoc test (GFC-Garcinielliptone FC: $25 \mathrm{mg} / \mathrm{kg}, 50 \mathrm{mg} / \mathrm{kg}$ and $75 \mathrm{mg} / \mathrm{kg}$ ).

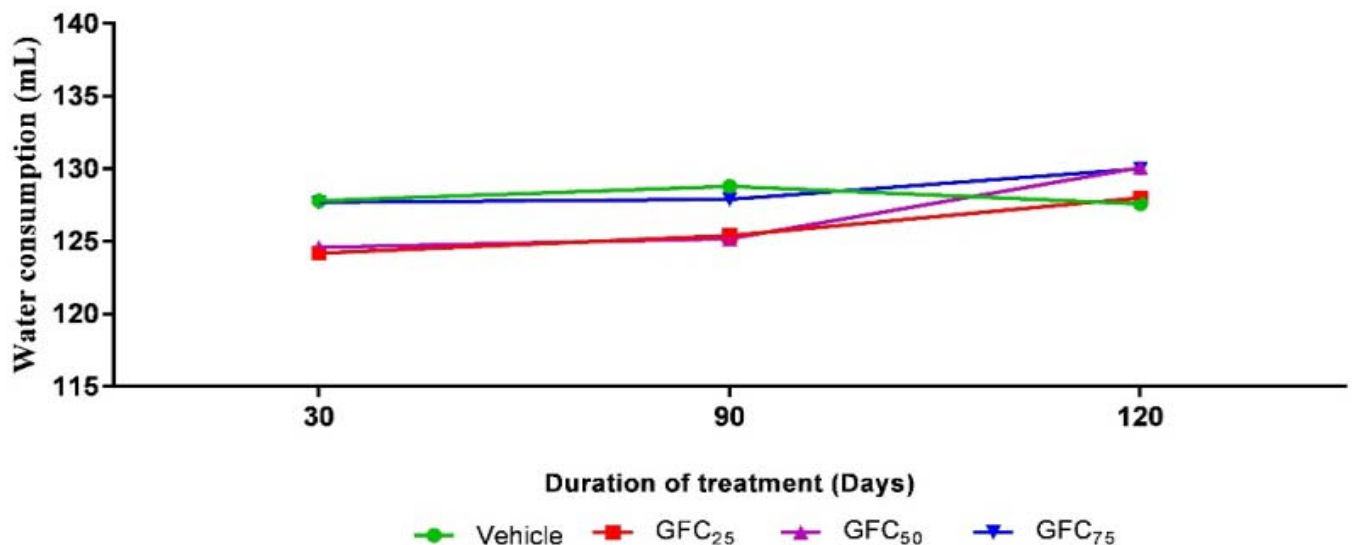

Fig. 3 Effect of oral administration of GFC in repeated doses on the water consumption of animals.

Statistical analysis was performed using ANOVA followed by t-Student-Newman-Keuls test as a post hoc test (GFC-Garcinielliptone FC: $25 \mathrm{mg} / \mathrm{kg}, 50 \mathrm{mg} / \mathrm{kg}$ and $75 \mathrm{mg} / \mathrm{kg}$ ).

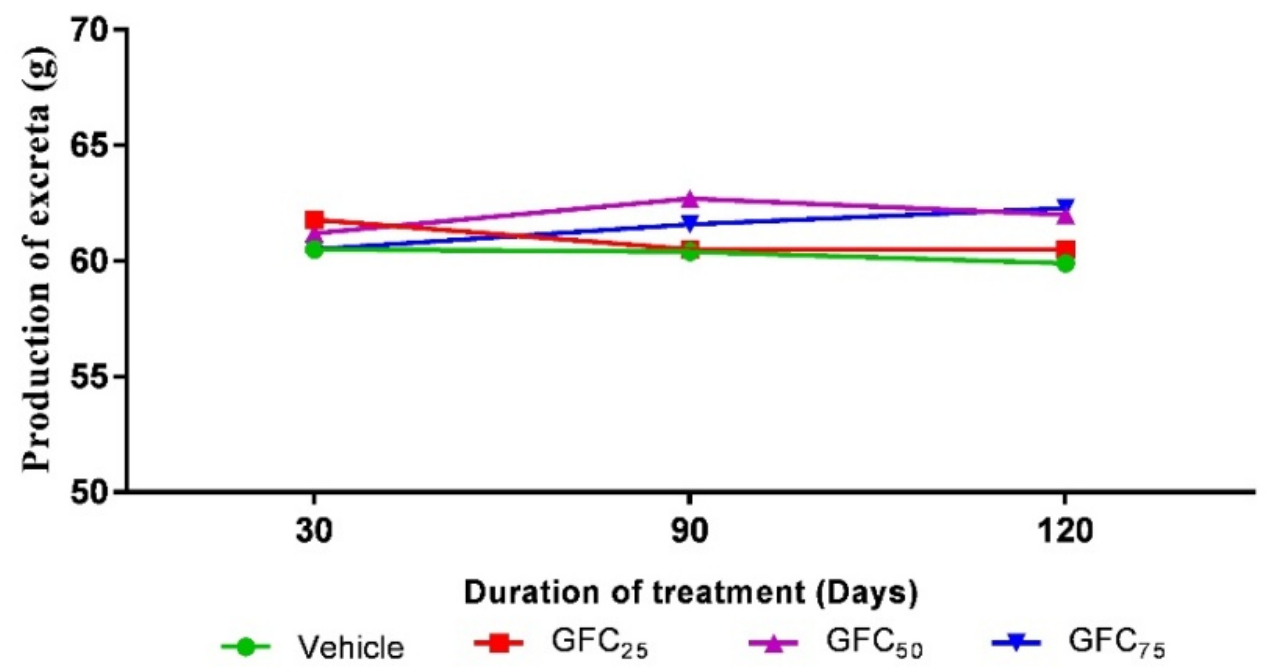

Fig. 4 Effect of oral administration of repeated doses of GFC production by animal excreta for 30, 90 and 120 days.

Statistical analysis was performed using ANOVA followed by t-Student-Newman-Keuls test as a post hoc test (GFC Garcinielliptone FC: $25 \mathrm{mg} / \mathrm{kg}, 50 \mathrm{mg} / \mathrm{kg}$ and $75 \mathrm{mg} / \mathrm{kg}$ ). 


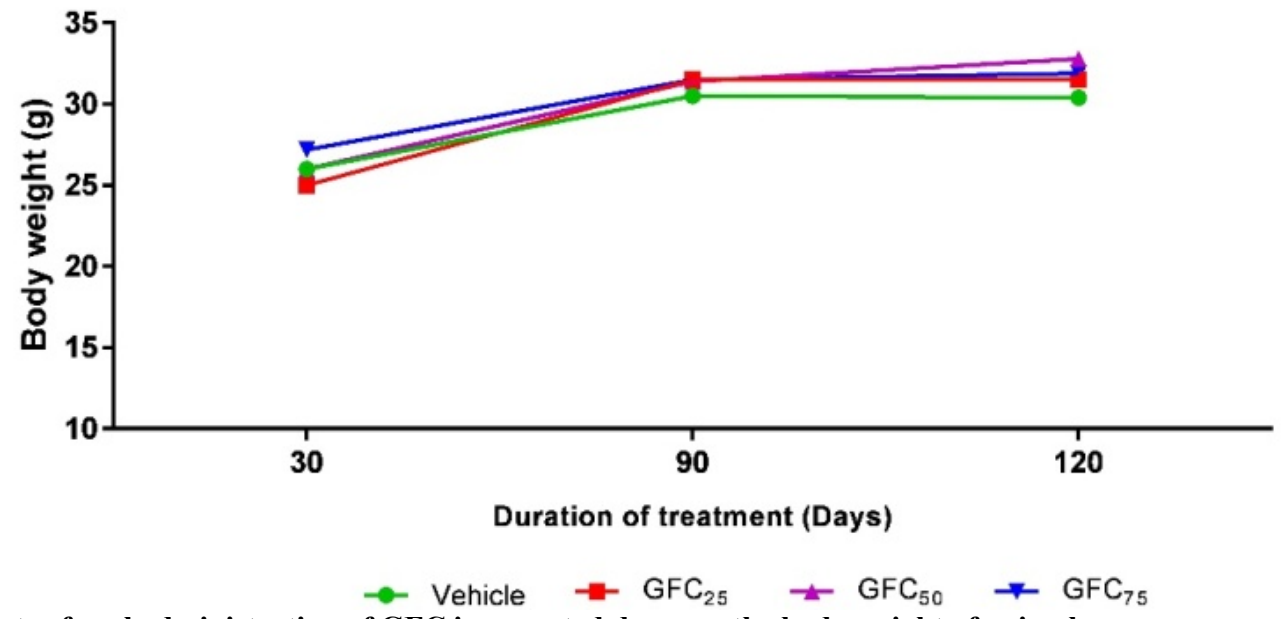

Fig. 5 Effects of oral administration of GFC in repeated doses on the body weight of animals.

Statistical analysis was performed using ANOVA followed by t-Student-Newman-Keuls test post hoc test (GFC: 25 mg/kg, $50 \mathrm{mg} / \mathrm{kg}$ and $75 \mathrm{mg} / \mathrm{kg})$.

$75 \mathrm{mg} / \mathrm{kg}$ compared with the control group $(P<0.05)$, respectively.

Furthermore, during treatment with GFC for 90 days, there was a reduction of $6 \%$ on the MCHC index in male mice after treatment with a dose of $75 \mathrm{mg} / \mathrm{kg}$ as compared with the control group $(P<0.05)$, and decreases of 5,7 and $7 \%$ in females on the MCHC index after treatment with doses of 25, 50 e $75 \mathrm{mg} / \mathrm{kg}$ when compared with the group control $(P<0.05)$ respectively.

Finally, similarly to these results, the administration of GFC for 120 days reduced by 3 and 4\% in male mice and by 7 and 12\% in females the MCHC index with doses of 50 and $75 \mathrm{mg} / \mathrm{kg}$ as compared with the control group $(P<0.05)$, respectively. Moreover, we detected a decrease of $25 \%$ in the number of leukocytes only in female mice after treatment with a dose of 50 and $75 \mathrm{mg} / \mathrm{kg}$ as compared with the control group $(P<0.05)$.

The biochemical parameters for animals treated with GFC are presented in Tables 4 and 5. Liver enzymes were measured in order to check possible kidney or liver damage in the experimental animals. Our study for toxicity evaluation of GFC determined the levels of urea and uric acid in MM (male mice) and FM (female mice) vehicle-treated and those treated with doses of GFC. After 30, 90 and 120 days administration, it was observed a decrease in the level of urea at 30 days (MM = 4.8, 4.7 and 6.3\%; FM: 4.8, 5.7 and 3.9\%, 90 Days (MM = 4.9, 6.3 and 6.7\%; FM: 6.44, 6.4 and 6.7\%) and 120 days ( $\mathrm{MM}=10.2,7.9$ and 8.4\%; FM: 8.1, 8.0 and 8.4\%), with doses administered consecutively. The contents of uric acid also decreased 30 days ( $\mathrm{MM}=5.1,4.1$ and 5.1\%; FM: 5.2, 3.5 and 2.6\%), 90 Days (MM = 4.1, 5.1 and 4.1\%; FM: 7.4, 5.2 and 3.9\%) and 120 days (MM = 7.6, 6.1 and 7.1\%; FM: 6.1, 5.2 and 8.3\%), with doses administered sequentially, compared with the control group $(P<0.05)$.

Similarly, cholesterol and triglycerides levels decreased from the groups orally treated with the repeated doses of GFC 25, 50 and $75 \mathrm{mg} / \mathrm{kg}$ : cholesterol levels at 30 days $(\mathrm{MM}=14.4,15.9$ and 9.8\%, FM: 16.7, 13.2 and 8.4\%), 90 days (MM = 7.8, 14.7 and 16.5\%; FM: 12.0, 15.7 and 17.1\%) and 120 days $(\mathrm{MM}=13.4,17.2$ and 17.3\%, FM: 23.6, 18.0 and $11.5 \%)$; triglyceride levels, $(\mathrm{MM}=10.9 \%$ (25 mg/kg), FM: 10,3\% (25 mg/kg)), 90 days $(\mathrm{MM}=8.5 \%(25$ $\mathrm{mg} / \mathrm{kg})$; FM: $12.7 \%(25 \mathrm{mg} / \mathrm{kg})$ ) and 120 days (MM = 12.5\% (25 mg / kg), FM: 16.5\% (25 mg/kg)) as compared with the control group $(P<0.05)$. Given these effects it can be suggested a beneficial role of this polyisoprenylated benzophenone serum in reducing triglycerides, that needs to be better evaluated. 
Table 2 Effect of repeated dose administration of GFC on hematological parameters of animals for 30,90 and 120 days of treatment.

\begin{tabular}{|c|c|c|c|c|c|c|c|c|c|c|}
\hline \multirow{3}{*}{ Parameters } & \multicolumn{4}{|c|}{30 Days } & \multicolumn{3}{|c|}{90 Days } & \multicolumn{3}{|c|}{120 Days } \\
\hline & Control & $\mathrm{GFC}_{25}$ & $\mathrm{GFC}_{50}$ & $\mathrm{GFC}_{75}$ & $\mathrm{GFC}_{25}$ & $\mathrm{GFC}_{50}$ & $\mathrm{GFC}_{75}$ & $\mathrm{GFC}_{25}$ & $\mathrm{GFC}_{50}$ & $\mathrm{GFC}_{75}$ \\
\hline & (Vehicle) & $(25 \mathrm{mg} / \mathrm{kg})$ & $(50 \mathrm{mg} / \mathrm{kg})$ & $(75 \mathrm{mg} / \mathrm{kg})$ & (25 mg/kg) & $(50 \mathrm{mg} / \mathrm{kg})$ & $(75 \mathrm{mg} / \mathrm{kg})$ & $(25 \mathrm{mg} / \mathrm{kg})$ & $(50 \mathrm{mg} / \mathrm{kg})$ & (75 mg/kg) \\
\hline \multicolumn{11}{|l|}{ Males } \\
\hline $\operatorname{RBCs}\left(\mathrm{mm}^{3}\right)$ & $9.08 \pm 0.25$ & $10.32 \pm 0.12$ & $10.70 \pm 0.72$ & $9.28 \pm 0.49$ & $9.10 \pm 0.42$ & $9.35 \pm 0.67$ & $9.94 \pm 0.35$ & $8.40 \pm 0.47$ & $9.45 \pm 0.55$ & $9.66 \pm 0.29$ \\
\hline Hemoglobin $\left(\mathrm{g} \mathrm{dL}^{-1}\right)$ & $14.41 \pm 0.07$ & $15.91 \pm 0.65$ & $15.63 \pm 1.10$ & $15.57 \pm 0.46$ & $14.41 \pm 1.48$ & $15.23 \pm 1.62$ & $15.19 \pm 2.67$ & $15.34 \pm 3.22$ & $15.34 \pm 3.45$ & $16.41 \pm 2.55$ \\
\hline Hematocrit (\%) & $43.31 \pm 1.17$ & $43.22 \pm 3.96$ & $43.51 \pm 2.75$ & $42.63 \pm 2.25$ & $43.31 \pm 2.27$ & $43.54 \pm 3.86$ & $46.67 \pm 3.67$ & $43.16 \pm 2.34$ & $45.16 \pm 1.34$ & $44.15 \pm 2.43$ \\
\hline VCM (fL) & $49.73 \pm 0.11$ & $47.32 \pm 1.07$ & $48.10 \pm 0.78$ & $49.82 \pm 1.00$ & $49.45 \pm 3.50$ & $48.16 \pm 3.67$ & $47.18 \pm 2.89$ & $49.37 \pm 2.67$ & $48.45 \pm 1.65$ & $49.56 \pm 2.64$ \\
\hline HCM (pg) & $17.58 \pm 0.02$ & $17.61 \pm 0.37$ & $17.22 \pm 0.20$ & $17.90 \pm 0.29$ & $18.45 \pm 3.78$ & $17.89 \pm 2.34$ & $17.89 \pm 2.13$ & $16.45 \pm 3.45$ & $17.45 \pm 2.14$ & $16.58 \pm 4.58$ \\
\hline $\mathrm{CHCM}\left(\mathrm{g} \mathrm{dL}^{-3}\right)$ & $38.87 \pm 0.45$ & $37.53 \pm 0.53$ & $36.73 \pm 0.21^{\mathrm{a}}$ & $36.13 \pm 0.42^{\mathrm{a}}$ & $38.15 \pm 2.67$ & $37.45 \pm 3.56$ & $36.56 \pm 3.23^{\mathrm{a}}$ & $38.16 \pm 2.34$ & $37.42 \pm 1.45^{\mathrm{a}}$ & $37.09 \pm 3.17^{\mathrm{a}}$ \\
\hline Platelets $\left(\mathrm{mm}^{3}\right)$ & $445.30 \pm 11.05$ & $444.92 \pm 12.85$ & $446.83 \pm 11.6$ & $446.24 \pm 11.9$ & $448.77 \pm 14.09$ & $447.78 \pm 12.16$ & $446.23 \pm 13.34$ & $447.37 \pm 14.18$ & $446.40 \pm 12.41$ & $446.48 \pm 13.50$ \\
\hline $\begin{array}{l}\text { Leukocytes total } \\
\left(\mathrm{mm}^{3}\right)\end{array}$ & $8.02 \pm 0.25$ & $7.89 \pm 0.25$ & $6.86 \pm 0.37^{\mathrm{a}}$ & $6.78 \pm 1.14^{\mathrm{a}}$ & $8.23 \pm 3.55$ & $8.50 \pm 4.56$ & $6.19 \pm 3.67^{\mathrm{a}}$ & $8.45 \pm 2.34$ & $8.56 \pm 1.45$ & $6.51 \pm 2.19^{\mathrm{a}}$ \\
\hline Neutrophils (\%) & $8.45 \pm 0.56$ & $8.54 \pm 1.45$ & $7.96 \pm 2.42$ & $8.46 \pm 2.22$ & $8.16 \pm 2.04$ & $8.89 \pm 2.67$ & $8.67 \pm 2.15$ & $8.40 \pm 3.34$ & $8.76 \pm 2.32$ & $9.43 \pm 2.51$ \\
\hline Lymphocytes (\%) & $74.33 \pm 0.04$ & $74.35 \pm 0.16$ & $74.36 \pm 0.16$ & $74.37 \pm 0.06$ & $74.33 \pm 3.18$ & $75.70 \pm 3.78$ & $75.79 \pm 3.42$ & $73.32 \pm 4.49$ & $73.34 \pm 3.34$ & $74.45 \pm 3.10$ \\
\hline \multicolumn{11}{|l|}{ Females } \\
\hline RBCs $\left(\mathrm{mm}^{3}\right)$ & $9.17 \pm 0.56$ & $9.83 \pm 0.12$ & $8.74 \pm 0.20$ & $8.91 \pm 0.95$ & $8.83 \pm 0.12$ & $9.74 \pm 0.20$ & $9.91 \pm 0.95$ & $9.51 \pm 0.48$ & $9.32 \pm 0.49$ & $9.78 \pm 0.71$ \\
\hline Hemoglobin $\left(\mathrm{g} \mathrm{dL}^{-1}\right)$ & $15.29 \pm 0.19$ & $14.10 \pm 2.26$ & $15.50 \pm 1.78$ & $16.38 \pm 1.24$ & $15.10 \pm 2.26$ & $15.50 \pm 1.78$ & $16.38 \pm 1.24$ & $14.46 \pm 3.34$ & $15.10 \pm 2.23$ & $15.39 \pm 3.14$ \\
\hline Hematocrit (\%) & $48.18 \pm 1.57$ & $47.25 \pm 2.75$ & $48.28 \pm 3.09$ & $48.60 \pm 2.25$ & $47.25 \pm 2.75$ & $48.28 \pm 3.09$ & $47.60 \pm 2.25$ & $47.31 \pm 3.18$ & $47.23 \pm 2.54$ & $48.84 \pm 3.95$ \\
\hline VCM (fL) & $52.64 \pm 0.10$ & $51.25 \pm 2.24$ & $51.46 \pm 1.37$ & $52.34 \pm 1.87$ & $51.25 \pm 2.24$ & $50.46 \pm 1.37$ & $51.34 \pm 1.87$ & $52.23 \pm 2.56$ & $51.35 \pm 2.61$ & $52.42 \pm 4.16$ \\
\hline HCM (pg) & $18.55 \pm 0.15$ & $18.20 \pm 2.28$ & $18.91 \pm 3.67$ & $17.71 \pm 2.22$ & $17.20 \pm 2.28$ & $17.91 \pm 3.67$ & $16.71 \pm 2.22$ & $17.27 \pm 3.16$ & $18.54 \pm 3.16$ & $18.29 \pm 2.17$ \\
\hline $\mathrm{CHCM}\left(\mathrm{g} \mathrm{dL}^{-3}\right)$ & $40.25 \pm 0.49$ & $38.23 \pm 2.16$ & $39.08 \pm 3.39$ & $37.40 \pm 2.85^{\mathrm{a}}$ & $38.23 \pm 2.16^{\mathrm{a}}$ & $37.40 \pm 3.39^{\mathrm{a}}$ & $37.08 \pm 2.85^{\mathrm{a}}$ & $38.54 \pm 3.17$ & $37.29 \pm 3.38^{\mathrm{a}}$ & $35.34 \pm 4.14^{\mathrm{a}}$ \\
\hline Platelets $\left(\mathrm{mm}^{3}\right)$ & $448.70 \pm 14.32$ & $447.15 \pm 12.16$ & $446.18 \pm 13.29$ & $448.50 \pm 14.26$ & $447.15 \pm 12.16$ & $445.18 \pm 13.29$ & $446.50 \pm 12.26$ & $446.34 \pm 14.38$ & $447.21 \pm 13.35$ & $446.34 \pm 14.27$ \\
\hline $\begin{array}{l}\text { Leukocytes total } \\
\left(\mathrm{mm}^{3}\right)\end{array}$ & $6.32 \pm 0.55$ & $6.30 \pm 2.21$ & $6.23 \pm 3.20$ & $6.61 \pm 2.80$ & $6.31 \pm 2.24$ & $5.16 \pm 3.36^{\mathrm{a}}$ & $6.58 \pm 2.35$ & $6.64 \pm 4.17$ & $6.25 \pm 3.41$ & $4.74 \pm 4.57^{\mathrm{a}}$ \\
\hline Neutrophils (\%) & $6.47 \pm 0.34$ & $6.31 \pm 2.28$ & $6.56 \pm 3.20$ & $5.35 \pm 3.26$ & $6.31 \pm 2.28$ & $6.56 \pm 3.20$ & $7.35 \pm 3.26$ & $6.24 \pm 3.47$ & $6.36 \pm 3.49$ & $6.24 \pm 4.01$ \\
\hline Lymphocytes (\%) & $72.45 \pm 2.45$ & $72.43 \pm 2.39$ & $70.18 \pm 3.53$ & $70.25 \pm 2.59$ & $72.43 \pm 2.39$ & $71.18 \pm 3.53$ & $71.25 \pm 2.59$ & $71.20 \pm 4.35$ & $71.41 \pm 2.38$ & $72.37 \pm 4.09$ \\
\hline
\end{tabular}

VCM (volume corpuscular mean); HCM (Hemoglobin Corpuscular Mean); CHMC (Concentration Hemoglobin Corpuscular Mean); Control (vehicle); GFC (Garcinielliptone FC $25 \mathrm{mg} / \mathrm{kg}, 50 \mathrm{mg} / \mathrm{kg}$ and $75 \mathrm{mg} / \mathrm{kg}$ ). Values represent the mean + S.E.M. $(\mathrm{n}=10)$. a $-P<0.05$ versus control (ANOVA followed by t test Student Newman Keuls as post hoc test). 
Table 3 Effect of repeated dose administration of GFC on biochemical parameters of animals for 30,90 and 120 days of treatment.

\begin{tabular}{|c|c|c|c|c|c|c|c|c|c|c|}
\hline \multirow[b]{2}{*}{ Parameters } & \multicolumn{4}{|c|}{30 Days } & \multicolumn{3}{|c|}{90 Days } & \multicolumn{3}{|c|}{ 120 Days } \\
\hline & $\begin{array}{l}\text { Control } \\
\text { (Vehicle) }\end{array}$ & $\begin{array}{l}\mathrm{GFC}_{25} \\
(25 \mathrm{mg} / \mathrm{kg})\end{array}$ & $\begin{array}{l}\mathrm{GFC}_{50} \\
(50 \mathrm{mg} / \mathrm{kg})\end{array}$ & $\begin{array}{l}\mathrm{GFC}_{75} \\
(75 \mathrm{mg} / \mathrm{kg})\end{array}$ & $\begin{array}{l}\mathrm{GFC}_{25} \\
(25 \mathrm{mg} / \mathrm{kg})\end{array}$ & $\begin{array}{l}\mathrm{GFC}_{50} \\
(50 \mathrm{mg} / \mathrm{kg})\end{array}$ & $\begin{array}{l}\mathrm{GFC}_{75} \\
(75 \mathrm{mg} / \mathrm{kg})\end{array}$ & $\begin{array}{l}\mathrm{GFC}_{25} \\
(25 \mathrm{mg} / \mathrm{kg})\end{array}$ & $\begin{array}{l}\mathrm{GFC}_{50} \\
(50 \mathrm{mg} / \mathrm{kg})\end{array}$ & $\begin{array}{l}\mathrm{GFC}_{75} \\
(75 \mathrm{mg} / \mathrm{kg})\end{array}$ \\
\hline \multicolumn{11}{|l|}{ Male } \\
\hline Brain (g\%) & $0.16 \pm 0.05$ & $0.15 \pm 0.10$ & $0.16 \pm 0.13$ & $0.17 \pm 0.16$ & $0.15 \pm 0.34$ & $0.16 \pm 0.45$ & $0.17 \pm 0.12$ & $0.15 \pm 0.13$ & $0.18 \pm 0.11$ & $0.15 \pm 0.11$ \\
\hline Spleen (g\%) & $0.07 \pm 0.01$ & $0.06 \pm 0.01$ & $0.08 \pm 0.03$ & $0.06 \pm 0.01$ & $0.07 \pm 0.01$ & $0.08 \pm 0.03$ & $0.06 \pm 0.01$ & $0.08 \pm 0.04$ & $0.09 \pm 0.01$ & $0.08 \pm 0.01$ \\
\hline Heart (g\%) & $0.15 \pm 0.09$ & $0.16 \pm 0.07$ & $0.16 \pm 0.03$ & $0.15 \pm 0.09$ & $0.16 \pm 0.07$ & $0.16 \pm 0.03$ & $0.15 \pm 0.09$ & $0.15 \pm 0.01$ & $0.14 \pm 0.05$ & $0.15 \pm 0.02$ \\
\hline Liver (g\%) & $0.74 \pm 0.18$ & $0.73 \pm 0.05$ & $0.75 \pm 0.02$ & $0.74 \pm 0.18$ & $0.73 \pm 0.05$ & $0.75 \pm 0.02$ & $0.74 \pm 0.18$ & $0.91 \pm 0.13$ & $0.87 \pm 0.12$ & $0.84 \pm 0.03$ \\
\hline Lungs (g\%) & $0.16 \pm 0.02$ & $0.15 \pm 0.09$ & $0.17 \pm 0.01$ & $0.16 \pm 0.02$ & $0.15 \pm 0.09$ & $0.17 \pm 0.01$ & $0.16 \pm 0.02$ & $0.14 \pm 0.02$ & $0.15 \pm 0.01$ & $0.16 \pm 0.01$ \\
\hline Kidneys (g\%) & $0.09 \pm 0.09$ & $0.04 \pm 0.03$ & $0.05 \pm 0.06$ & $0.05 \pm 0.08$ & $0.04 \pm 0.03$ & $0.05 \pm 0.06$ & $0.05 \pm 0.08$ & $0.12 \pm 0.01$ & $0.11 \pm 0.05$ & $0.10 \pm 0.02$ \\
\hline \multicolumn{11}{|l|}{ Female } \\
\hline Brain (g\%) & $0.16 \pm 0.01$ & $0.15 \pm 0.09$ & $0.16 \pm 0.09$ & $0.16 \pm 0.11$ & $0.15 \pm 0.09$ & $0.16 \pm 0.09$ & $0.16 \pm 0.11$ & $0.18 \pm 0.10$ & $0.17 \pm 0.12$ & $0.16 \pm 0.12$ \\
\hline Spleen (g\%) & $0.08 \pm 0.01$ & $0.06 \pm 0.01$ & $0.07 \pm 0.02$ & $0.07 \pm 0.02$ & $0.06 \pm 0.01$ & $0.07 \pm 0.02$ & $0.07 \pm 0.02$ & $0.07 \pm 0.02$ & $0.08 \pm 0.03$ & $0.09 \pm 0.02$ \\
\hline Heart (g\%) & $0.15 \pm 0.09$ & $0.14 \pm 0.01$ & $0.15 \pm 0.03$ & $0.15 \pm 0.03$ & $0.14 \pm 0.01$ & $0.15 \pm 0.03$ & $0.15 \pm 0.03$ & $0.13 \pm 0.08$ & $0.13 \pm 0.01$ & $0.14 \pm 0.03$ \\
\hline Liver (g\%) & $0.74 \pm 0.18$ & $0.74 \pm 0.20$ & $0.76 \pm 0.08$ & $0.76 \pm 0.08$ & $0.74 \pm 0.20$ & $0.76 \pm 0.08$ & $0.76 \pm 0.08$ & $0.69 \pm 0.03$ & $0.72 \pm 0.07$ & $0.71 \pm 0.01$ \\
\hline Lungs (g\%) & $0.16 \pm 0.02$ & $0.15 \pm 0.10$ & $0.15 \pm 0.05$ & $0.15 \pm 0.05$ & $0.15 \pm 0.10$ & $0.15 \pm 0.05$ & $0.15 \pm 0.05$ & $0.13 \pm 0.02$ & $0.15 \pm 0.02$ & $0.14 \pm 0.03$ \\
\hline Kidneys (g\%) & $0.09 \pm 0.09$ & $0.04 \pm 0.03$ & $0.05 \pm 0.06$ & $0.05 \pm 0.06$ & $0.04 \pm 0.03$ & $0.05 \pm 0.06$ & $0.05 \pm 0.06$ & $0.04 \pm 0.01$ & $0.05 \pm 0.05$ & $0.04 \pm 0.02$ \\
\hline \multirow{3}{*}{ Parameters } & \multicolumn{4}{|c|}{30 Days } & \multicolumn{3}{|c|}{90 Days } & \multicolumn{3}{|c|}{120 Days } \\
\hline & Control & $\mathrm{GFC}_{25}$ & $\mathrm{GFC}_{50}$ & $\mathrm{GFC}_{75}$ & $\mathrm{GFC}_{25}$ & $\mathrm{GFC}_{50}$ & $\mathrm{GFC}_{75}$ & $\mathrm{GFC}_{25}$ & $\mathrm{GFC}_{50}$ & $\mathrm{GFC}_{75}$ \\
\hline & (Vehicle) & $(25 \mathrm{mg} / \mathrm{kg})$ & $(50 \mathrm{mg} / \mathrm{kg})$ & $(75 \mathrm{mg} / \mathrm{kg})$ & $(25 \mathrm{mg} / \mathrm{kg})$ & $(50 \mathrm{mg} / \mathrm{kg})$ & $(75 \mathrm{mg} / \mathrm{kg})$ & $(25 \mathrm{mg} / \mathrm{kg})$ & $(50 \mathrm{mg} / \mathrm{kg})$ & $(75 \mathrm{mg} / \mathrm{kg})$ \\
\hline \multicolumn{11}{|l|}{ Male } \\
\hline Brain (g\%) & $0.16 \pm 0.05$ & $0.15 \pm 0.10$ & $0.16 \pm 0.13$ & $0.17 \pm 0.16$ & $0.15 \pm 0.34$ & $0.16 \pm 0.45$ & $0.17 \pm 0.12$ & $0.15 \pm 0.13$ & $0.18 \pm 0.11$ & $0.15 \pm 0.11$ \\
\hline Spleen (g\%) & $0.07 \pm 0.01$ & $0.06 \pm 0.01$ & $0.08 \pm 0.03$ & $0.06 \pm 0.01$ & $0.07 \pm 0.01$ & $0.08 \pm 0.03$ & $0.06 \pm 0.01$ & $0.08 \pm 0.04$ & $0.09 \pm 0.01$ & $0.08 \pm 0.01$ \\
\hline Heart (g\%) & $0.15 \pm 0.09$ & $0.16 \pm 0.07$ & $0.16 \pm 0.03$ & $0.15 \pm 0.09$ & $0.16 \pm 0.07$ & $0.16 \pm 0.03$ & $0.15 \pm 0.09$ & $0.15 \pm 0.01$ & $0.14 \pm 0.05$ & $0.15 \pm 0.02$ \\
\hline Liver (g\%) & $0.74 \pm 0.18$ & $0.73 \pm 0.05$ & $0.75 \pm 0.02$ & $0.74 \pm 0.18$ & $0.73 \pm 0.05$ & $0.75 \pm 0.02$ & $0.74 \pm 0.18$ & $0.91 \pm 0.13$ & $0.87 \pm 0.12$ & $0.84 \pm 0.03$ \\
\hline Lungs (g\%) & $0.16 \pm 0.02$ & $0.15 \pm 0.09$ & $0.17 \pm 0.01$ & $0.16 \pm 0.02$ & $0.15 \pm 0.09$ & $0.17 \pm 0.01$ & $0.16 \pm 0.02$ & $0.14 \pm 0.02$ & $0.15 \pm 0.01$ & $0.16 \pm 0.01$ \\
\hline Kidneys (g\%) & $0.09 \pm 0.09$ & $0.04 \pm 0.03$ & $0.05 \pm 0.06$ & $0.05 \pm 0.08$ & $0.04 \pm 0.03$ & $0.05 \pm 0.06$ & $0.05 \pm 0.08$ & $0.12 \pm 0.01$ & $0.11 \pm 0.05$ & $0.10 \pm 0.02$ \\
\hline \multicolumn{11}{|l|}{ Female } \\
\hline Brain (g\%) & $0.16 \pm 0.01$ & $0.15 \pm 0.09$ & $0.16 \pm 0.09$ & $0.16 \pm 0.11$ & $0.15 \pm 0.09$ & $0.16 \pm 0.09$ & $0.16 \pm 0.11$ & $0.18 \pm 0.10$ & $0.17 \pm 0.12$ & $0.16 \pm 0.12$ \\
\hline Spleen (g\%) & $0.08 \pm 0.01$ & $0.06 \pm 0.01$ & $0.07 \pm 0.02$ & $0.07 \pm 0.02$ & $0.06 \pm 0.01$ & $0.07 \pm 0.02$ & $0.07 \pm 0.02$ & $0.07 \pm 0.02$ & $0.08 \pm 0.03$ & $0.09 \pm 0.02$ \\
\hline Heart (g\%) & $0.15 \pm 0.09$ & $0.14 \pm 0.01$ & $0.15 \pm 0.03$ & $0.15 \pm 0.03$ & $0.14 \pm 0.01$ & $0.15 \pm 0.03$ & $0.15 \pm 0.03$ & $0.13 \pm 0.08$ & $0.13 \pm 0.01$ & $0.14 \pm 0.03$ \\
\hline Liver (g\%) & $0.74 \pm 0.18$ & $0.74 \pm 0.20$ & $0.76 \pm 0.08$ & $0.76 \pm 0.08$ & $0.74 \pm 0.20$ & $0.76 \pm 0.08$ & $0.76 \pm 0.08$ & $0.69 \pm 0.03$ & $0.72 \pm 0.07$ & $0.71 \pm 0.01$ \\
\hline Lungs (g\%) & $0.16 \pm 0.02$ & $0.15 \pm 0.10$ & $0.15 \pm 0.05$ & $0.15 \pm 0.05$ & $0.15 \pm 0.10$ & $0.15 \pm 0.05$ & $0.15 \pm 0.05$ & $0.13 \pm 0.02$ & $0.15 \pm 0.02$ & $0.14 \pm 0.03$ \\
\hline Kidneys (g\%) & $0.09 \pm 0.09$ & $0.04 \pm 0.03$ & $0.05 \pm 0.06$ & $0.05 \pm 0.06$ & $0.04 \pm 0.03$ & $0.05 \pm 0.06$ & $0.05 \pm 0.06$ & $0.04 \pm 0.01$ & $0.05 \pm 0.05$ & $0.04 \pm 0.02$ \\
\hline
\end{tabular}

The values represent the mean \pm S.E.M. $(\mathrm{n}=10)$ animals. “\%” represents the relative weight calculated based on the absolute organ weight $(\mathrm{g})$ the value of live animal weight $(\mathrm{g}) \mathrm{x}$ 100. $P<0.05$ compared to the control group (one-way ANOVA). 
In turn, the concentration of ALT was decreased 30 days $(\mathrm{MM}=8.6$ and 8.4\%, FM: 8.2 and 8.0\%), 90 days $(\mathrm{MM}=8.2$ and 8.3\%, FM: 10.4\% and 9.5) and 120 days $(\mathrm{MM}=9.8$ and 7.2\%, FM: 13.9 and 9.7\%), only by the doses of 25 and $50 \mathrm{mg} / \mathrm{kg}$, respectively, compared with the control group $(P<0.05)$. Similarly, there was a decrease on AST, 30 days $(\mathrm{MM}=2.9$ and 3.5\%; FM: $8.05 \%$ and 5.6\%), 90 days ( $\mathrm{CM}=2.3$ and 4.0\%, FM: $12.7 \%$ and $8.0 \%)$ and 120 days (MM = 6.0 and 4.9\%, FM: 16.2 and 9.2\%); at doses of 25 and 50 $\mathrm{mg} / \mathrm{kg}$ compared with the control group $(P<0.05)$. For this reason we suggest that dose increasing does not produce an increase in toxicity, since the observed changes in AST and ALT were detected with lower doses.

\subsection{Gross Morphological Analysis}

In toxicity studies of repeated doses the main parameters evaluated are the general toxic signs, dietary changes, laboratory aspects and pathologic evaluation and behavioral [22].

In macroscopic anatomical review of the main dissected organs of male and female mice which underwent the treatment with repeated doses of GFC (animals Table 4), did not show significant changes compared to the control group $(P<0.05)$.

Additionally, there was no significant difference in the weights of the major organs (brain, spleen, heart, liver, lung and kidney) of male and female animals treated orally with doses of 25, 50 e $75 \mathrm{mg} / \mathrm{kg}$ of GFC compared to the control group. The dose also did not have a deleterious effect on the organs analyzed after treatment with repeated doses.

\section{Discussion}

The acute or chronic evaluation of the toxicity of bioactive compounds is of great relevance and interest for the pharmaceutical, cosmetic and/or food industry. Because they may interfere with several biological mechanisms, including the production of blood cells or damage to major organs that reveal important role in vital functions of the organism with biotransformation and/or excretion [23]. These data suggest that the toxicological safety profile of medicinal plants should be drawn, since its use in folk medicine is increasingly carried out by the Brazilian population, particularly the inhabitants of the state of Piaui, which has easy access to $P$. insignis and products derived from parts of the plant of this species. Furthermore, the safety assessment on the use of herbal medicines has recently been questioned due to reports of deaths and diseases, which reinforces the need for the present study [24, 25].

In the present study, complementing tests on the acute toxicity of a single dose of GFC were made [26] by oral administration repeated doses of GFC. This study was carried out with the aim of evaluating the qualitative and quantitative effects for a long period of exposure, providing latency for the installation of toxic effects and the consequent appearance after the accumulation of the substance in the body during preclinical trials.

Literature has demonstrated numerous toxicological studies with plant extracts or isolated compounds from plants with therapeutic effect, which makes it increasingly necessary to establish parameters for toxicity to other species used in Brazilian folk medicine [24, 27]. The species $P$. insignis cannot be considered an herbal yet, but the GFC isolated from the hexane extract of its seeds has been used in various experimental protocols and has demonstrated several biological properties such as anti-inflammatory [28], antioxidant [1, 29], antileishmanial, cytotoxic [30] and vasorelaxing properties in rat mesenteric artery [31]. These data and the present study are useful to provide more information to strengthen the rational therapy and safety margins of pharmaceutical, cosmetic and/or food products originated from this species, such as, folk juices, ice creams, jellies, among others by the Brazilian Northeast population.

In this context, acute toxicity with repeated doses 
makes reference to the cumulative adverse effects of substances administration, preferably orally, in a limited period of time (15-30 days) [32]. In our study, administration of the substance GFC for 30 days in both sexes, demonstrated that this compound is not able to induce mortality and/or changes in behavior in adult mice. Moreover, body weight gain, feed intake and excreta disposal were not altered by acute administration with repeated doses of GFC. Our results confirm data found for the species of the genus Garcinia which belongs to the same family of $P$. insignis.

The studies with repeated doses for 30, 90 and 120 consecutive days are differentiated by the period of exposure of the animals to the GFC, aiming to verify toxicological effects for a long exposure on biochemical, hematological and physiological parameters of male and female adult mice [33]. Regarding the consumption of food and water, there were no significant differences on these parameters over the days of treatment as well as the volume of excreta was proportional to ingestion, suggesting the absence of interference of GFC on both parameters and on the main bodies' responses for metabolism and excretion.

The changes in body mass in studies of long-term toxicity are important indicators of adverse effects of a substance in animal's laboratory [34, 35]. By means of this parameter it was possible to verify that, after repeated dosing, GFC increased the body weight of the animals, indicating a minimal or no degree of toxicity of this compound. As a general rule, most investigators consider the gain or loss of body weight is of toxicological significance if the reduction is at least by $10 \%$ compared to the average of the control group [36, 37]. We can stress that this compound can be considered slightly toxic and therefore safe to be used in industrial process for obtaining technological products for human and/or animal medical practice

In our study through the Hippocratic Screening, a previous screening test useful in the evaluation of pharmacological and toxicological activities $[15,19$, 38], no changes were detected in general activity, awareness and sensitivity of male and female mice treated with doses of GFC in 25, 50 e $75 \mathrm{mg} / \mathrm{kg}$. In addition, there were subtle changes on the autonomic nervous system and the absence of feces in individual during the treatment, suggesting a possible presence of mild constipation. However, it is notable that despite this observation, the animals in groups treated with GFC and the control group were uniformly healthy at the end of the administration period and in each of the experimental protocols, suggesting a mild toxicity for this compound isolated from $P$. insignis. In addition, to evaluate the toxicity parameters, Hippocratic Screening is important to consider the effects of GFC on the hematopoietic system, which is one of the most sensitive target for toxic compounds and is an important index for the physiological and pathological state of rodents. Moreover, changes in blood profile usually provide vital information about the body's response to tissue injury [39]. Daily administration of GFC for 120 days produced no significant changes in hematological parameters of male and female mice treated at all doses, and the changes found may be considered toxicologically irrelevant as they were within the limits of references, demonstrating the slight toxicity of this compound [40]. These data also suggest that this compound cannot exhibit toxic effects on the hematopoietic system, ensuring safe use of this substance in animals and generating promising future expectations for clinical studies.

Although, a general model of the biochemical profile of the animals were within the reference values [26], there were exceptions for urea, uric acid, triglycerides, cholesterol, AST and ALT. The reduction of urea and uric acid in plasma levels indicate an improvement on renal function, suggesting GFC can be evaluated in experimental models that detect kidney failure, to ensure that it can be used during a treatment of acute renal failure besides GFC 
can also be applied in order to produce a reduction in protein catabolism when its needed in some pathological conditions [41]. On the other hand, the increase in plasma levels of urea and creatinine provides evidence of renal overload, acute renal failure and increased protein catabolism [42, 43]. In this study, a decrease in the serum levels of urea and uric acid were observed in the groups treated with GFC for 30, 90 and 120 days. Thus, it can be suggested that its use can be made safely, since no renal overload was observed in the mice.

In addition to these results, with regard to the biochemical parameters, cholesterol and total triglyceride levels were reduced in male and female mice treated with GFC for 30, 90 and 120 days. However, a pharmacological research on the possible hypolipidemic effect is required, since the doses were used to identify toxic parameters [44]. The assessment of the effects of the GFC on the biochemical parameters, the analysis of serum aminotransferase enzymes (ALT and AST) are important indicators of lesions in liver cells [26]. GFC does not cause any damage to the liver without interfering with the normal activity of these enzymes [44, 45]. The present study suggests that the use of GFC for 30, 90 and 120 cannot induce hepatotoxicity, since a significant reduction of AST and ALT were observed, suggesting that the compound may induce a hepatoprotective effect, which needs to be better investigated [43].

Complementing the toxicological evaluation, it is important to perform a macroscopic morphological study, which is an important index to diagnose whether a body has been exposed to an injury, and can be done by calculating the ratio between the organ weights versus body weight of the animal [46]. In our study, no differences in weight and macroscopic structure of the brain, liver, kidney, lung, heart and spleen between groups of adult male and female mice treated with doses of GFC at 25, 50 e $75 \mathrm{mg} / \mathrm{kg}$ for 30 , 90 and 120 days were observed when compared to the control group [27].
Our observations indicate that the polyisoprenylated benzophenones in GFC have a wide margin of safety in experimental animals commonly used in preclinical studies with emphasis on evaluation of toxicity. However, despite the knowledge of mild toxicity of GFC established in this study, it may be suggested that further studies should be conducted as in-depth investigation of hyper cholesterolemia in animals in order to prove the findings and advance the assessment of the safety use of GFC for the design of pharmaceutical, cosmetic and/or food formulations, since the species which GFC was isolated from is widely used in cooking and in popular medicine in Northeast Brazil.

\section{Conclusions}

These results indicate that treatment with repeated doses of GFC showed no haematological and biochemical toxicity, particularly in hepatic and renal parameters. In addition, GFC reduced triglyceride levels, which need to be investigated in animal models of hypercholesterolemia. Thus, in our study, the oral administration of GFC at 25, 50 and $75 \mathrm{mg} / \mathrm{kg}$ for 30, 90 and 120 days, in both sexes, demonstrates that the polyisoprenylated benzophenones in GFC have a good margin of safety in experimental animals commonly used in preclinical studies with emphasis on evaluation of toxicity.

\section{Acknowledgement}

We would like to thank the Research Supporting Foundation of the State of Piaui (FAPEPI/Brazil), MinCyT (Argentina)-CAPES (Brazil) for the financial support. We also would like to thank Stênio Gardel Maia for help us with the English revision and M.S.F. acknowledge doctoral fellowships from CONICET.

\section{References}

[1] Costa-Junior, J. S., Almeida, A. A. C., Tomé, A. R., Citó, A. M. G. L., Saffi, J., and Freitas, R. M. 2011. "Evaluation of Possible Antioxidant and Anticonvulsant Effects of the Ethyl Acetate Fraction from Platonia 


\section{a Polyisoprenylated-Benzophenone Isolated from Seed of Platonia Insignis Mart}

Insignis Mart. (Bacuri) on Epilepsy Models.” Epilepsy and Behavior 22: 678-84.

[2] Agra, M. F., Freitas, P. F., and Barbosa-Filho, J. M. 2007. "Synopsis of the Plants Known as Medicinal and Poisonous in Northeast of Brazil.” Brazilian Journal of Pharmaceutical Sciences 17: 114-40.

[3] Costa-Junior, J. S., Ferraz, A. B. F., Filho, B. A. B., Feitosa, C. M., Citó, A. M. G. L., Freitas, R. M., and Saffi, J. 2011. "Evaluation of In Vitro Antioxidant Effects of Garcinielliptone FC (GFC) Isolated from Platonia Insignis Mart.” Journal of Medicinal Plants Research 52: 293-9.

[4] Piccinelli, A. L., Cuesta-Rubio, O., Chica, M. B., Mahmood, N. B., Pagano, M., Pavone, M., Barone, V., and Rastrelli, L. 2005. "Structural Revision of Clusianone and 7-Epi-clusianone and Anti-HIV Activity of Polyisoprenylated Benzophenones.” Tetrahedron 61: 8206-11.

[5] Chen, X. Q., Li, C. X., Cheng, X., Wang, K., He, J., Pan, Z. H., Li, M. M., Peng, L. Y., Xu, G., and Zhao, Q. S. 2010. "Polycyclic Polyprenylated Acylphloroglucinols and Chromone O-glucosides from Hypericum Henryi Subsp. Uraloides.” Chemistry and Biodiversity 7: 196-204.

[6] Kumar, S., Sharma, S., and Chattopadhyay, S. K. 2013. "The Potential Health Benefit of Polyisoprenylated Benzophenones from Garcinia and Related Genera: Ethnobotanical and Therapeutic Importance.” Phytotherapy 89: 86-125.

[7] Alves, T. M., Alves, R., Romanha, A. J., Zani, C. L., Dos Santos, M. H., and Nagem, T. J. 1999. "Biological Activities of 7-Epiclusianone.” Journal of Natural Products 62: 369-71.

[8] Santos, M. H., Nagem, T. J., Oliveira, T. T., and Braz-Filho, R. 1999. "7-Epiclusianone, the New Tetraprenylated Benzophenone and Others Chemical Constituents from the Fruits of Rheedia Gardneriana.” Química Nova 22: 654-60.

[9] Santos, P. R. P., Carvalho, R. B. F., Costa-Junior, J. S., Freitas, R. M., and Feitosa, C. M. 2013. "Survey of Physical Chemical and Pharmacological Properties of Extracts and Compounds Isolated from Platonia Insignis Mart. A Perspective for the Development of Herbal Medicines.” Brazilian Journal of Pharmaceutical Sciences 94: 161-8.

[10] Monache, F. D., Monache, G. D., Moura Pinheiro, R., and Radics, L. 1988. "Nemorosonol, a Derivative of Tricyclo-[4.3.1.03, 7]-Decane-7-Hydroxy-2, 9-Dione from Clusia Nemorosa.” Phytochemistry 27: 2305-8.

[11] Gustafson, K. R., Blunt, J. W., Munro, M. H. G., Fuller, R. W., McKee, T. C., and Cardellina, J. H. 1992. "The Guttiferones, HIV-inhibitory Benzophenones from
Symphonia Globulifera, Garcinia Livingstonei, Garcinia Ovalifolia, and Clusia Rosea." Tetrahedron 48: 10093-102.

[12] Cuesta-Rubio, O., Frontana-Uribe, B. A., Ramirez-Apan, T., and Cardenas, J. 2002. "Polyisoprenylated Benzophenones in Cuban Propolis; Biological Activity of Nemorosone Zeitschrift Für Naturforschung. C. J.” Biosciences 57: 372-8.

[13] Baggett, S., Protiva, P., Mazzola, E. P., Yang, H., Ressler, E. T., Basile, M. J., Weinstein, I. B., and Kennelly, E. J. 2005. "Bioactive Benzophenones from Garcinia Xanthochymus Fruits.” Journal of Natural Products 68: 354-60.

[14] Graff, S. 2006. Fundamentos de Toxicologia Clínica. São Paulo: Atheneu, 157.

[15] Lucio, E. M. R. A., Rosalen, P. L., Sharapin, N., and Brito, A. R. M. S. 2000. “Acute Toxicological Evaluation and Screening of the Hippocratic Epilsopilosina Secondary Alkaloid Pilocarpus Microphyllus Stapf.” Brazilian Journal of Pharmaceutical Sciences 9: 23-5.

[16] Bakoma, B., Berkéb, B., Eklu-Gadegbekua, K., Agbonona, A., Aklikokoua, K., Gbeassora, M., Creppyc, E. E., and Mooreb, N. 2013. “Acute and Sub-chronic (28 days) Oral Toxicity Evaluation of Hydroethanolic Extract of Bridelia Ferruginea Benth Root Bark in Male Rodent Animals.” Food and Chemical Toxicology 52: 176-9.

[17] Malone, M. H., and Robichaud, R. C. 1983. "The Pharmacological Evaluation of Natural Products-General and Specific Approaches to Screening Ethnopharmaceuticals.” Journal of Ethnopharmacology 8: 127-47.

[18] Santos e Silva, A. P., Sousa, G. F., Freitas, R. M., and Nunes, L. C. C. 2012. "Evaluation of Acute Toxicity of the Watery Extract of Orbignya Phalerata Mart Mesocarp Powder (Babaçu)." Revista Cubana de Plantas Medicinales 17: 393-401.

[19] Cunha, L. C., Azeredo, F. S., Mendonça, A. C. V., Vieira, M. S., Pucci, L. L., Valadares, M. C., Freitas, H. O. G., Sena, A. A. S., and Lino-Junior, R. S. 2009. "Evaluation of Acute and Subacute Toxicity in Rats, the Ethanol Extract of Leaves and Latex Synadenium Umbellatum Pax. Braz.” Journal of Pharmaceutical Sciences 19: 403-11.

[20] Flecknell, P. 1996. Laboratory Animal Anaesthesia. London: Academic Press, 11-4.

[21] Kohn, D. F., Wixson, S. K., White, W. J., and Benson, G. J. 1997. Anaesthesia and Analgesia in Laboratory Animals. American College of Laboratory Animal Medicine Series. San Diego: Academic Press, 381-2.

[22] Oga, S., Camargo, M. M. A., and Batistuzzo, J. A. O. 2008. Essentials of Toxicology. São Paulo: Atheneu, 677.

[23] Park, M., Choi, H., Kim, J. H., Lee, H., and Ku, S. 2010. 
“28 Days Repeated Dose Oral Toxicity Test of Aqueous Extracts of Mahwangyounpae Teng, the Pohyherbal Formula." Food and Chemical Toxicology 48: 2477-82.

[24] Lather, A., Valecha, R., Sharma, K., and Garg, M. 2011. "World Wide Potential of Plants Causing Teratogenicityan Overview.” Spatula DD 1: 101-6.

[25] Mabona, U., and Van Vuuren, S. F. 2013. "Southern African Medicinal Plants Used to Treat Skin Diseases South African.” Journal of Botany 87: 175-93.

[26] Silva, A. R. H., Moreira, L. R., Brum, E. S., Freitas, M. L., Boligon, A. A., Athayde, M. L., Romanc, S. S., Mazzanti, C. M., and Brandão, R. 2014. "Biochemical and Hematological Effects of Acute and Sub-acute Administration to Ehyl Acetate Fraction from the Stem Bark Scutia Buxifolia Reissek in Mice.” Journal of Ethnopharmacology 153: 908-16.

[27] Tchamadeu, M. C., Dzeufiet, P. D. D., Nana, P., Kouambou-Nouga, C. C., Ngueguim-Tsofack, F., Allard, J., Blaes-Siagat, N. R., Zapfack, L., Girolami, J. P., Tack, I., Kamtchouing, P., and Dimo, T. 2011. “Acute and Sub-chronic Oral Toxicity Studies of an Aqueous Stem Bark Extract of Pterocarpus Soyauxii Taub (Papilionaceae) in Rodents.” Journal of Ethnopharmacology 133: 329-35.

[28] Weng, J. R., Tsao, L. T., Wang, J. P., Wu, R. R., and Lin, C. N. 2004. "Antinflammatory Phloroglucinols and Terpenoids from Garcinia Subelliptica.” Journal of Natural Products 67: 1796.

[29] Costa-Junior, J. S., Almeida, A. A., Costa, J. P., Citó, A. M. G. L., Saffi, J., and Freitas, R. M. 2012. "Superoxide Dismutase and Catalase Activities in Rat Hippocampus Pretreated with Garcinielliptone FC from Platonia Insignis.” Pharmaceutical Biology 50: 453-7.

[30] Costa-Junior, J. S., Almeida, A. A., Ferraz, A. B. F., Rossatto, R. R., Silva, T. G., Silva, P. B., Militão, G. C., Citó, A. M. G. L., Santana, L. C. L. R., Carvalho, F. A. A., and Freitas, R. M. 2013. "Cytotoxic and Leishmanicidal Properties of Garcinielliptone FC, the Prenylated Benzophenone from Platonia Insignis.” Natural Product Research 27: 470-4.

[31] Arcanjo, D. D., Costa-Júnior, J. S., Moura, L. H., Ferraz, A. B., Rossatto, R. R., David, J. M., Quintans-Júnior, L. J., Oliveira, R. D.; Citó, A. M., and Oliveira, A. P. 2014. "Garcinielliptone FC, a Polyisoprenylated Benzophenone from Platonia Insignis Mart., Promotes Vasorelaxant Effect on Rat Mesenteric Artery." Natural Product Research 27: 470-4.

[32] Steuer, J., Björck, M., Mayer, D., Wanhainen, A., Pfammatter, T., and Lachat, M. 2013. "Distinction between Acute and Chronic Type B Aortic Dissection: Is There a Sub-acute Phase?” European Journal of Vascular and Endovascular Surgery 45: 627-31.

[33] Bednarczuk, V. O., Verdam, M. C. S., Miguel, M. D., and Miguel, O. G. 2010. "In Vitro and In Vivo Used in Toxicological Screening of Natural Products.” Visão Acadêmica 11: 43-50.

[34] Sireatawong, S., Lertprasertsuke, N., Srisawat, U., Thuppia, A., Ngaamjariyawat, A., Suwannlihio, N., and Jaijoy, K. 2008. “Acute and Sub-chronic Toxicity Study of the Water Extract from Tiliacora Trianora (Colebr) Diels in Rats.” Songklanakarin Journal of Science and Technology 30: 729-37.

[35] Da Silva, E. R., Diedrich, D., Bolzan, R. C., and Giacomelli, S. R. 2012. “Toxicological and Pharmacological Evaluation of Discaria American Gillies and Hook (Rhamnaceae) in Mice.” Brazilian Journal of Pharmaceutical Sciences 48: 273-80.

[36] Hayes, A. 2008. Principles and Methods of Toxicology. New York: Informa Healthcare.

[37] Lu, L., Fan, Y., Yao, W., Xie, W., Guo, J., Yan, Y., Yang, F., and $\mathrm{Xu}$, L. 2014. "Safety Assessment of the Fermented Phylloporia Ribis (Lonicera Japon Thunb.) Mycelia by Acute Oral Toxicity Study in Mice and 90-Day Feeding Study in Rats.” Food and Chemical Toxicology 69: 18-24.

[38] Cunha, L. C., Melo, D. F. A., Pereira, M. E., Melo, D. S., Parente, L. L., Silva, M. A. C., Conceição, E. C., and Gonzaga, L. Q. S. 2013. "Evaluation of Acute Toxicity of Aqueous Extract of Apeiba Tibourbou Aubl (Tiliaceae) in Mice and Rats.” Revista de Ciências Farmacêuticas Básica e Aplicada. 34: 357-62.

[39] Mukinda J. T. and Eagles F. K. 2010. “Acute and Sub-chronic Oral Toxicity Profile of the Aqueous Extract of Pohygala Fruticosa in Female Mice and Rats.” Journal of Ethnopharmacology 128: 236-40.

[40] Derelanko, M. J. and Rusch, G. M. 2008. "Adolor Corporation, Exton, Pennsylvania, USA.” Drug and Chemical Toxicology 31: 97-114.

[41] Campelo, L. M. L., Sá, C. G., Feitosa, C. M. I., Sousa, G. F., and Freitas, R. M. 2013. "Chemical and Toxicological Studies Constituents of the Essential Oil Extracted from Citrus Limon on Burn (Rutaceae).” Revista Brasileira de Plantas Medicinais 15: 708-16.

[42] Costa-Silva, J. H, Lima, C. R., Silva, E. J. R., Araujo, A. V., Fraga, M. C., Ribeiro-Ribeiro, A., Arruda, A. C., Lafayette, S. S. L., and Wanderley A. G. 2008. “Acute and Subacute Toxicity of the Carapa Guianensis Aublet (Meliaceae) Seed Oil.” Journal of Ethnopharmacology 116: 495-500.

[43] Silva, M. G. B., Aragao, T. P., Vasconcelos, C. F. B., Ferreira, P. A., Andrade, B. A., Costa, I. M. A., Costa-Silva, J. H., Wanderley, A. G., and Lafayatte, S. S. L. 2011. "Acute and Subacute Toxicity of Cassia 


\section{a Polyisoprenylated-Benzophenone Isolated from Seed of Platonia Insignis Mart}

Occidentalis L. Stem and Leaf in Wistar Rats.” Journal of Ethnopharmacology 136: 341-6.

[44] Zhao, T., Mao, G., Zhang, M., Zou, Y., Feng, W., Gu, X., Yang, Z., Mao, R., and Wu, L. Y. X. 2014. "Enhanced Antitumor Effect and Reduced Toxicity of Schisanreae Polysaccharide in 5-Fu Treated HEPS-Bearing Mice.” International Journal of Biological Macromolecules 63: 114-8.

[45] Hamza, N., Berke, B., Cheze, C., Agli, A. N., Robinson,
P., Gin, H., and Moore, N. 2010. "Prevention of Type 2 Diabetes Induced by High Fat Diet in the C57BL/6J Mouse by Two Medicinal Plants Used in Traditional Treatment of Diabetes in the East of Algeria.” Journal of Ethnopharmacology 128: 513-8.

[46] Rosidah, Y. M. F., Sadikun, A., Ahmad, M., Akowuah, G A., and Asmawi, M. Z. 2009. "Toxicology Evaluation of Standardized Methanol Extract of Gynura Procumbens.” Journal of Ethnopharmacology 123: 244-9. 